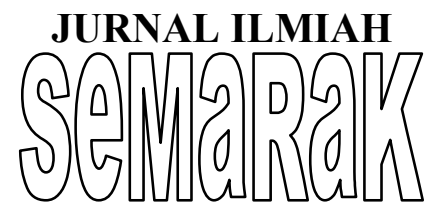

P-ISSN 2615-6849, E-ISSN 2622-3686

Jurnal Semarak,Vol. 1,No.3,Oktober 2018 , Hal (88-106)

@Prodi Manajemen Fakultas Ekonomi Universitas Pamulang

\title{
PENGARUH RISK BASED CAPITAL DAN BEBAN KLAIM TERHADAP LABA PADA PERUSAHAAN ASURANSI JIWA PERIODE 2014 - 2016
}

\author{
Firdaus Budhy Saputro \\ Staff Pengajar Program Studi Pendidikan Ekonomi FIPPS Universitas Indraprasta PGRI \\ Email: ovier2008@gmail.com
}

\begin{abstract}
ABSTRAK
Kajian ini bertujuan untuk menentukan kesan sebahagiannya antara variabel modal berasaskan risiko ke atas pendapatan dalam syarikat insurans hayat bagi tempoh 2014-2016, untuk menentukan kesan sebahagiannya antara beban pemboleh ubah tuntutan ke atas pendapatan dalam syarikat insurans hayat bagi tempoh 2014-2016, untuk menentukan kesan secara serentak antara pemboleh ubah modal berasaskan risiko dan beban tuntutan ke atas pendapatan dalam syarikat insurans hayat bagi tempoh 2014-2016. Sampel dalam kajian ini adalah 44 syarikat insurans hayat. Keputusan kajian menunjukkan bahawa terdapat kesan separa antara modal berasaskan risiko dan perbelanjaan tuntutan yang mempengaruhi pendapatan. Hasil kajian ini juga menunjukkan bahawa variabel modal berasaskan risiko dan perbelanjaan tuntutan mempunyai kesan serentak yang signifikan ke atas pendapatan. Dalam ujian penentuan terdapat kesan $69.3 \%$ yang mempengaruhi keuntungan yang dijelaskan oleh variabel modal berasaskan risiko dan perbelanjaan tuntutan, manakala baki 30,7\% dapat memberikan pengaruh oleh pembolehubah lain dan tidak ada dalam penelitian ini.
\end{abstract}

Kata kunci: risk based capital, beban klaim, laba.

\section{ABSTRACT}

The purpose of this study is to determine the effect of some of the risk-based capital variables on income in life insurance companies for the period 2014-2016, to determine the effect of partly on the burden of variable claims on earnings in life insurance companies for the period 20142016, to determine the impact simultaneously between risk-based capital variables and claims load on income in life insurance companies for the period 2014-2016. The samples in this study were 44 life insurance companies. The results of the study show that there is a partial impact between risk-based capital and claims spending affecting income. The findings also show that risk-based capital variables and claims expenses have a significant simultaneous impact on income. In the determination test there was an impact of $69.3 \%$ affecting profits explained by risk-based capital variables and claims spending, while the remaining $30.7 \%$ could have influence by other variables and did not exist in this study.

Key words: risk based capital, expense claims, profit.

\section{PENDAHULUAN}

\section{A. Latar Belakang}

OJK (Otoritas Jasa Keuangan) melaporkan tercatat pada tahun 2015 dimana laba komprehensif asuransi pada quartal pertama diangka Rp. 2,979 milyar.
Mengalami peningkatan di quartal ke dua sebesar $16.27 \%$. Quartal ketiga mengalami sedikit penurunan tetapi di quartal ke empat mengalami peningkatan di angka Rp. 5,459 milyar. Maraknya perkembangan insurans jiwa di Indonesia, 
Jurnal Semarak,Vol. 1,No.3,Oktober 2018 , Hal (88-106)

@ Prodi Manajemen Fakultas Ekonomi Universitas Pamulang

terlihat bahwa data yang dijabarkan oleh AAJI terkait dengan laba asuransi jiwa tahun 2016, total industri dari perusahaan asuransi jiwa secara komprehensif telah mencatat sebesar Rp. 5,46 triliun. Sebagai suatu perbandingan, berdasarkan data dari OJK, kenyataanya laba dari perusahaan asuransi pada tahun 2014 sebesar Rp. 15,85 triliun. Akibatnya, sebelas (11) bulan dari 2015, pendapatan laba komprehensif mengalami peurunan sebesar $65,55 \%$ pada basis tahun-ke-hari (seperti tahun lalu). November 2015, laba industri asuransi jiwa meningkat menjadi 42\% dari Oktober 2015 sebesar Rp. 3,88 triliun.

AAJI bersetuju dengan OJK bahawa keuntungan syarikat insurans hayat meningkat sebanyak 22\%. Pendapatan insurans hayat pada Desember 2016 berjumlah Rp. 8.46 trilion, naik $24 \%$ kepada Rp. 5,2 trilion dibndingkan pada00 bulan sebelumnya, November. Desember menjadi keuntungan insurans hayat tertinggi sejak September. Kerana berbanding pertumbuhan keuntungan September dan Oktober hanya $12 \%$. Pendapatan insurans hayat pada bulan November dikekalkan oleh pendapatan insurans hayat meningkat menjadi $12.5 \%$, berjumlah Rp. 98.05 trilion dari Rp. 78.72 trilion pada bulan Oktober. Sementara itu, dari sisi perbelanjaan, terdapat peningkatan sebesar $12.4 \%$ menjadi $\mathrm{Rp}$. 86,44 triliun pada Desember dari $\mathrm{Rp}$.
80.16 trilion pada bulan Desember (prestasi industri insurans hayat 2016 konvensional).

Sedangkan untuk melihat kesehatan kinerja keuangan perusahaan asuransi salah satu faktornya adalah pendapatan premi, Menurut Radiks Purba dalam (Nugraha), Pengaruh Pengunderaitan, Perbelanjaan Tuntutan dan Hasil Pelaburan Terhadap Keuntungan Bersih dalam Kerugian Syarikat Insurans yang tersenarai di Bursa Saham Indonesia untuk tempoh 2008-2012, 2014), Menjelaskan bahwa pendapatan premi merupakan “imbalan jasa atas jaminan yang diberikan oleh penanggung kepada tertanggung untuk mengganti kerugian yang mungkin diderita oleh tertanggung dengan menyediakan sejumlah keuntungan terhadap resiko dihari tua maupun resiko kematian". Selain itu terdapat beberapa faktor lainnya yang memperngaruhi laba perusahaan asuransi diantaranya: Risk Based Capital dan Nilai Investasi. Radiks

Purba dalam (Nugraha, Pengaruh Pengunderaitan, Perbelanjaan Tuntutan dan Hasil Pelaburan Terhadap Keuntungan Bersih dalam Kerugian Syarikat Insurans yang tersenarai di Bursa Saham Indonesia untuk tempoh 20082012, 2014), juga menjelaskan bahwa Investasi adalah menginvestasikan uang untuk tujuan memperoleh laba. Sedangkan hasil investasi pada dasarnya adalah pendapatan dari portofolio investasi aset 
perusahaan asuransi. Di sisi lain menurut Peraturan Pemerintah (PP) No. 63 tahun 2004 menyatakan bahwa RBC Risk Based Capital (RBC) rasio kesehatan adalah ukuran yang menginformasikan tingkat keamanan keuangan atau kesehatan perusahaan asuransi yang harus dipenuhi oleh kerugian perusahaan asuransi 120\%. Semakin besar rasio kesehatan RBC (Risk Based Caital) sebuah perusahaan asuransi, semakin sehat kondisi keuangan perusahaan.

Laba syarikat insuran jiwa pada paruh pertama tahun 2016 tumbuh secara year on year (YOY). Pertumbuhan laba terdorong daripada pertumbuhan premium dan hasil pelaburan yang tumbuh. Data Otoritas Jasa Keuangan (OJK) mencatat laba insurans jiwa Rp. 8,95 triliun naik $158 \%$ pada bulan juni 2016. Hal ini tertopang perolehan hasil investasi yang mendaki menjadi Rp. 13,03 triliun tumbuh $183 \%$. Serta premi yang tumbuh $18,5 \%$ pada tahun 2007 menjadi Rp. 61,17 triliun.

Laba yang tinggi adalah "tanda mengenai pengguna yang mengharapkan suatu output lebih dari industri / perusahaan. Sebaliknya, laba yang rendah atau rugi adalah tanda bahwa konsumen kurang menginginkan produk / komoditi yang ditangani dan metode produksinya tidak efisien".

Pendapatan laba adalah "ukuran keuntungan dengan membandingkan laba setelah bunga dan cukai berbanding dengan jualan. Rasio ini menunjukkan pendapatan bersih jualan syarikat. Baik Marjin Laba pada Jualan dan Marjin Laba Bersih jika rasionya tinggi ini menunjukkan kemampuan menghasilkan laba yang tinggi pada tingkat penjualan tertentu, sebaliknya jika rasionya rendah menandakan penjualan yang terlalu rendah untuk tingkat tingkatan tertentu, atau kombinasi dari kedua hal tersebut. Rasio yang rendah dapat menunjukkan ketidakseimbangan pengurusan.

Salah satu faktor penentu kelangsungan hidup perusahaan adalah penghasilan. Untuk bertahan dan bersaing dengan perusahaan dalam menarik keuntungan di pasar, perusahaan harus memiliki strategi yang baik dan efektif dilaksanakan oleh seluruh stakeholder. Oleh karena itu, perusahaan harus bersaing dalam menangkap pasar kepercayaan dalam bisnis mereka. Pasar kepercayaan adalah modal yang kuat yang mempengaruhi keuntungan perusahaan. Membangun kepercayaan pasar untuk membeli produk yang ditawarkan akan menjadi sebuah tantangan yang unik dan menarik bagi perusahaan asuransi.

Kewujudan insurans kini hadir sebagai institusi yang terlibat dalam insurans. Institusi-institusi insurans berkembang pesat bersama-sama dengan pertumbuhan ekonomi negara di Indonesia. Pada masa ini, insurans telah 
Jurnal Semarak,Vol. 1,No.3,Oktober 2018 , Hal (88-106)

(a)Prodi Manajemen Fakultas Ekonomi Universitas Pamulang

memberi manfaat kepada banyak individu dan entiti perniagaan. Terdapat beberapa jenis produk insurans termasuk; insurans hayat, insurans am, insurans kesihatan dan insurans pendidikan. Dalam perbincangan kajian ini akan dibincangkan satu jenis produk yang akan dibincangkan ialah Insurans Hayat. (Pasar Polis Indonesia, Definisi Insurans dan Manfaat.

\section{Definisi asuransi (Faradois,} 2013:13) Insurans adalah sebuah institusi ekonomi yang memiliki tujuan untuk mengurangkan suatu risiko dengan menggabungkan beberapa objek pengurusan yang jumlahnya agak besar, jadi kewujudan kemungkinan terjadinya risiko kerugian secara keseluruhan dapat diramalkan dalam batas-batas tertentu.

Berdasarkan definisi di atas yang telah dinyatakan oleh beberapa pakar, dapat dibuat suatu kesimpulan bahwa "asuransi adalah perjanjian antara dua pihak yaitu pihak tertanggung dan pihak penanggung yang bertujuan guna mengurangi risiko dengan cara pihak tertanggung melakukan pembayaran premi (iuran) secara teratur sesuai dengan rentang waktu yang ditentukan kepada pihak penanggung sebagai pergantian polis yang menjamin perlindungan terhadap risiko seseorang yang kemungkinan terjadi di masa yang akan datang".
Salah satu perkara utama yang dapat dilihat adalah kesolvenan syarikat insurans. Kadar kesolvenan syarikat insurans di Indonesia ditentukan oleh nilai Capital Based Risk (RBC). Menurut Peraturan Menteri Keuangan No.53 / PMK.10 / 2012, dijelaskan bahwa perusahaan asuransi setiap tahun harus menetapkan target tingkat kesolvenan terendah sebesar $120 \%$ dari modal berbasis risiko minimum. Modal minimum berasaskan risiko adalah jumlah dana yang diperlukan untuk menjangkakan risiko kerugian yang mungkin cagaran akibat penyimpangan dalam pengurusan aset dan liabiliti.

Beban klaim yang terdapat pada perusahaan asuransi umumnya merupakan beban yang berhubungan dengan pencairan yang dilakukan oleh nasabah termasuk tuntutan yang dipersetujui, tuntutan dalam proses penyelesaian, dan tuntutan yang telah berlaku tetapi belum dilaporkan. Beban klaim terjadi apabila terjadi kecelakaan, sakit yang harus dirawat di rumah sakit dan kematian atas tertanggung serta pemutusan kontrak dalam masa periode kontrak, atau dikenal dengan penebusan. Dalam hal ini perusahaan mengakui klaim sebagai pengurangan pendapatan premi, pada saat bukti- bukti yang sah telah diperoleh atasan tuntutan klaim yang terjadi. Pengakuan beban klaim dapat mempengaruhi besarnya laba. 
Jurnal Semarak,Vol. 1,No.3,Oktober 2018 , Hal (88-106)

@ Prodi Manajemen Fakultas Ekonomi Universitas Pamulang

Setelah dijabarkan berdasarkan teori

- teori yang dijabarkan, penyelidik berminat menjalankan penyelidikan yang berjudul "Pengaruh Risk Based Capital

Dan Beban Klaim terhadap Laba Pada Perusahaan Asuransi Jiwa Periode 2014 - 2016".

\section{B. Rumusan Masalah}

Analisa mengenai latar belakang faktor-faktor yang boleh menjelaskan keuntungan (laba) yang digariskan oleh pengarang, perkara-perkara utama dalam perumusan isu-isu yang akan dibincangkan termasuk:

1. Apakah ada pengaruh parsial pada variabel risk based capital terhadap laba pada perusahaan asuransi jiwa untuk periode 2014-2016?

2. Apakah ada pengaruh parsial pada variabel beban klaim terhadap laba pada perusahaan asuransi jiwa untuk periode 2014-2016?

3. Apakah ada pengaruh simultan pada variabel risk based capital dan beban klaim pada pendapatan di perusahaan asuransi jiwa untuk periode 2014-2016?

\section{Tujuan Penelitian}

Penjelasan yang dijabarkan mengenai latar belakan dan rumusan masalah, objektif dalam kajian dapat dijabarkan seperti berikut:

1. Mengetahui kesan sebahagiannya pemboleh ubah risk based capital ke atas pendapatan dalam syarikat insurans hayat bagi tempoh 2014-2016.

2. Untuk mengetahui kesan sebahagiannya antara beban tuntutan pemboleh ubah ke atas pendapatan dalam syarikat insurans hayat bagi tempoh 2014-2016.

3. Untuk mengetahui kesan serentak antara risk based capital dan tuntutan keuntungan dalam syarikat insurans hayat bagi tempoh 2014-2016.

\section{TINJAUAN PUSTAKA}

\section{A. Manajemen Keuangan}

Sartono, 2010 berpendapat mengenai manajemen keuangan yaitu "manajemen keuangan dapat diartikan sebagai manajemen dana baik yang berkaitan dengan pengalokasian dana dalam berbagai bentuk investasi secara efektif maupun usaha pengumpulan dana untuk pembiayaan investasi atau pembelanjaan secara efisien".

Husnan, 2010 mengatakan bahwa "manajemen keuangan merupakan aktiviti perancangan, belanjawan. Memeriksa, mengurus, mengawal, mencari dan menyimpan dana yang dimiliki oleh suatu organisasi atau syarikat".

Berdasarkan pendapat pakar di atas, dapat disimpulkan bahwa pengurusan keuanagan adalah "pengelolaan dana, yang berhubungan mengenai peruntukan

keuangan (dana) dalam suatu bentuk penanaman modal dengan efisien dengan kegiatan perencanaan, penganggaran. 
Memeriksa, mengurus, mengawal, mencari dan menyimpan dana yang dimiliki oleh suatu organisasi atau syarikat. Tujuan utama pengurusan kewangan syarikat adalah untuk memaksimumkan keuntungan yang akan diperoleh dan memaksimumkan kebajikan para pemegang saham yang boleh diukur dengan harga saham syarikat. Menurut (Sartono, 2010: 15), tujuan pengurusan kewangan adalah:

1. Memaksimumkan Keuntungan

Objektif utama secara umum apa yang ingin dicapai oleh pengurus kewangan ialah memaksimumkan keuntungan. Tetapi matlamat seperti ini mempunyai banyak kelemahan. Pertama, standard ekonomi memaksimumkan keuntungan adalah statik. Kedua, pemahaman keuntungan boleh mengelirukan, ketiga adalah risiko yang berkaitan dengan setiap keputusan alternatif.

2. Memaksimumkan Kemakmuran Para Investor

Merujuk kepada kelemahankelemahan ini, matlamat untuk dicapai oleh pengurus kewangan bukan untuk memaksimumkan keuntungan, tetapi memaksimumkan kemakmuran pemegang saham (Memaksimumkan Kekayaan Pemegang Saham) dengan memaksimumkan nilai syarikat. Memaksimumkan kemakmuran para pemegang saham dapat dicapai dengan memaksimumkan nilai sekarang dari semua manfaat pemegang saham yang diharapkan dapat diperoleh pada masa akan datang. Kemakmuran pemegang saham akan meningkat jika harga saham mereka meningkat juga.

\section{B. Signaling Theory}

Teori Isyarat menunjukkan bagaimana syarikat harus menyediakan isyarat kepada pengguna penyata kewangan. Isyarat ini adalah dalam bentuk maklumat mengenai apa yang telah dilakukan oleh pihak pengurusan untuk merealisasikan hasrat pemiliknya. Isyarat boleh dalam bentuk promosi atau maklumat lain yang menyatakan bahawa syarikat itu lebih baik daripada syarikat lain. Dalam teori isyarat membincangkan masalah asimetri maklumat di pasaran. Teori ini menerangkan bagaimana maklumat asimetri dapat dikurangkan dengan cara, satu pihak menyediakan isyarat maklumat kepada pihak yang lain.

Teori Singnaling menerangkan mengapa syarikat mempunyai keinginan untuk memberikan maklumat penyata kewangan kepada pihak luar, kerana terdapat maklumat asimetri antara syarikat dan pihak luar. Syarikat (agent) lebih mengetahui tentang syarikat dan prospek masa depan daripada pihak luar (pelabur, pemiutang). Kekurangan maklumat di luar syarikat menyebabkan mereka melindungi 
perusahaan dengan menyediakan price yang menurun dalam syarikat. Syarikat boleh meningkatkan nilai syarikat, dengan mengurangkan asimetri maklumat. Satu cara untuk mengurangkan asimetri maklumat ialah memberikan isyarat kepada pihak luar, salah satunya adalah maklumat kewangan yang boleh dipercayai dan akan mengurangkan ketidakpastian tentang prospek syarikat yang akan datang.

Di dalam rangka teori isyarat, ia menyatakan bahawa usaha syarikat untuk memberikan maklumat adalah kerana terdapat asimetri maklumat antara pengurus syarikat dan orang luar, ini kerana pengurus syarikat tahu lebih banyak maklumat mengenai syarikat dan prospek masa depan daripada pihak luar (Wolk, et al. 2000) Syarikat boleh meningkatkan nilai syarikat dengan mengurangkan asimetri maklumat. Satu cara untuk mengurangkan asimetri maklumat ialah memberikan isyarat kepada orang luar, dalam bentuk maklumat kewangan yang positif dan boleh dipercayai yang akan mengurangkan ketidakpastian mengenai prospek syarikat masa depan supaya ia dapat meningkatkan kredibiliti dan kejayaan syarikat (Wolk, et al., 2000).

Kenyataan kewangan harus memberikan maklumat yang berguna kepada pelabur dan pemiutang terutama kerana kumpulan ini berada dalam keadaan ketidakpastian yang paling besar, yang akan digunakan untuk membuat keputusan pelaburan, kredit dan keputusan yang sama, termasuk penyata aliran tunai kerana penyata aliran tunai adalah sebahagian daripada penyata kewangan.

\section{Laporan Keuangan}

"Laporan keuangan adalah maklumat yang menggambarkan keadaan kewangan sesebuah syarikat, dan maklumat lanjut boleh digunakan sebagai ilustrasi prestasi kewangan syarikat" (Fahmi, 2014:31).

Argumen lainnya oleh farida dan siwanto menyatakan bahwa "laporan keuangan merupakan informasi yang diharapkan mampu memberikan bantuan kepada pengguna untuk membuat keputusan ekonomi yang bersifat finansial"

Diperkuat oleh Munawir yang menyatakan bahwa "laporan keuangan merupakan alat yang sangat penting untuk memperoleh informasi sehubungan dengan posisi keuangan dan hasil-hasil yang telah dicapai oleh perusahaan yang bersangkutan". Dengan cara itu, penyata kewangan dijangka dapat membantu pengguna (user) membuat keputusan ekonomi kewangan. (Fahmi, 2014:31).

Lapo Penyata kewangan secara amnya terdiri daripada: (1) kunci kira-kira 
Jurnal Semarak,Vol. 1,No.3,Oktober 2018 , Hal (88-106)

@ Prodi Manajemen Fakultas Ekonomi Universitas Pamulang

yang menunjukkan kedudukan kewangan,

(2) laporan keuntungan dan kerugian yang membentangkan hasil perniagaan, (3) laporan perubahan modal yang menyesuaikan baki permulaan dan akhir semua akaun dalam seksyen ekuiti pemegang saham lembaran imbangan, (4) penyata aliran tunai yang menyediakan maklumat mengenai aliran tunai ke dalam dan luar aktiviti operasi, pembiayaan dan pelaburan dalam tempoh perakaunan, (5) Nota kepada laporan perakaunan. Kenyataan kewangan diperlukan untuk mengukur keputusan perniagaan dan perkembangan syarikat dari semasa ke semasa dan untuk mengetahui sejauh mana perusahaan mencapai matlamatnya.

Penjelasan mengenai laporan keuangan dijabarkan oleh Kasmir dan Jakfar, (2010:25), yang menyatakan bahwa "Laporan keuangan adalah laporan yang menunjukkan posisi keuangan perusahaan pada saat ini atau dalam suatu periode tertentu, laporan keuangan dibuat per periode misalnya tiga bulan atau enam bulan untuk kepentingan internal perusahaan. Sementara itu, untuk laporan luas dilakukan satu tahun sekali. Selain itu dapat diketahui posisi perusahaan terkini setelah menganalisis laporan keuangan tersebut dianalisis".
"Laporan kewangan adalah laporan yang menggambarkan kedudukan kewangan syarikat dalam tempoh tertentu, dan hasil perniagaannya dalam tempoh tertentu digunakan oleh pihak yang memerlukan laporan tersebut, baik pihak internal maupun pihak luar. Kenyataan kewangan adalah sumber maklumat yang sangat penting untuk mengetahui dan menganalisis keadaan kewangan syarikat dan dari hasil analisa dapat digunakan sebagai rujukan untuk pembuatan keputusan yang sesuai. Penyata kewangan yang dianalisis dalam analisis penyata kewangan adalah dua kali, iaitu kunci kira-kira dan penyata pendapatan. Penyata kewangan adalah hasil akhir proses perakaunan. Sebagai hasil akhir proses perakaunan, penyata kewangan menyediakan maklumat yang berguna untuk membuat keputusan oleh pelbagai pihak, seperti pemilik syarikat atau pemiutang" (Suwiknyo, 2010:42).

Menurut Harahap Menggariskan jawatan penyata kewangan ke dalam unit maklumat yang lebih kecil dan melihat hubungan mereka yang penting atau mempunyai makna antara satu sama lain, baik data kuantitatif dan data bukan kuantitatif dengan tujuan untuk mengetahui keadaan kewangan yang lebih mendalam yang sangat penting dalam 
proses menghasilkan keputusan yang tepat".

Dari pengertian yang dijabarkan, maka dapat dibuat suatu kesimpulan bahawa penyata kewangan adalah laporan yang menggambarkan kedudukan kewangan syarikat dalam suatu tempoh tertentu, dan hasil perniagaannya dalam jangka waktu tertentu digunakan oleh pihak yang memerlukan laporan baik pihak internal maupun pihak luar.

\section{Pengertian Asuransi}

Menurut (Ardiansyah, 2010) insurans adalah "institusi ekonomi yang mengurangkan risiko dengan menggabungkan di bawah satu pengurusan dan kumpulan objek dalam keadaan supaya kerugian besar yang ditanggung oleh suatu kumpulan boleh diramalkan dalam skop yang lebih kecil". Sedangkan (Supriyono, 2013) mendefinisikan asuransi "sebagai alat untuk mengurangkan risiko dengan menggabungkan beberapa unit berisiko supaya kerugian individu boleh diramalkan secara kolektif. Kerugian yang dapat diramal kemudian dibahagikan dan diedarkan secara proporsional antara semua unit dalam gabungan". (Ardiansyah, 2010) lihat insurans dari dua pandangan. Pertama, insurans adalah "perlindungan terhadap risiko kewangan oleh syarikat insurans dan kedua, insurans adalah alat di mana risiko dua atau lebih orang atau syarikat digabungkan melalui sumbangan premium yang ditentukan atau ditentukan sebagai dana yang digunakan untuk membayar tuntutan". Daripada pelbagai pendapat ini, dapat disimpulkan bahawa insurans merupakan institusi kewangan yang berfungsi untuk menanggung risiko kewangan (Ardiansyah, 2010).

Asuransi jiwa adalah "insurans yang menyediakan perkhidmatan dalam tindak balas risiko yang berkaitan dengan kehidupan atau kematian orang yang diinsuranskan”. Insurans kerugian adalah "perniagaan insurans yang menyediakan perkhidmatan untuk mengatasi risiko kerugian, kehilangan faedah, dan tanggung jawab undang-undang terhadap pihak ketiga yang timbul daripada peristiwa yang tidak menentu" (Ardiansyah, 2010).

Syarikat insurans hayat mesti memenuhi kesihatan kewangan mengikut peruntukan undang-undang dalam bidang insurans, seperti had tahap solvabilitas (solvency margin).

Menurut PSAK 36 (Revisi 2010) tentang asuransi jiwa, terdapat beberapa karakteristik asuransi jiwa yaitu:

1. Perniagaan insurans hayat adalah sistem perlindungan yang menghadapi risiko kewangan untuk kehidupan seseorang atau kematian dan pada masa 
Jurnal Semarak,Vol. 1,No.3,Oktober 2018 , Hal (88-106)

@ Prodi Manajemen Fakultas Ekonomi Universitas Pamulang

yang sama adalah satu usaha untuk meningkatkan dana awam.

2. Premium adalah pendapatan syarikat insurans, sebagai tambahan kepada pulangan pelaburan yang tidak dapat dipisahkan dari perniagaan insurans hayat.

3. Pelaburan fungsian utama adalah untuk memenuhi semua tanggungjawab faedah yang akan diberikan kepada pihak yang diinsuranskan.

4. Kewajipan kewangan syarikat insurans hayat berkaitan dengan ketidakpastian sesuatu peristiwa, ini memberi kesan kepada pembentangan penyata kewangan.

5. Penyata kewangan sangat dipengaruhi oleh unsur anggaran, contohnya anggaran jumlah liabiliti untuk manfaat dasar masa depan (liability for future policy benefits) dikira berdasarkan pengiraan aktuari, anggaran jumlah premium yang belum lagi pendapatan (unearned premium income), Anggaran amaun liabiliti tuntutan, serta anggaran jumlah tuntutan yang telah berlaku tetapi belum dilaporkan (incurred but not reported claims).

6. Pihak yang diinsuranskan (pembeli kontrak insurans) terlebih dahulu membayar premium insurans atau deposit premium kepada syarikat insurans sebelum kejadian atau kejadian yang diinsuranskan. Bayaran ini adalah pendapatan (revenue) untuk syarikat insurans. Apabila kontrak insurans diluluskan, syarikat insurans biasanya tidak tahu sama ada ia akan membayar faedah insurans, berapa bayarannya, dan jika ia berlaku, apabila ia akan berlaku. Ini akan menjejaskan isu pengiktirafan pendapatan dan pengukuran beban.

7. Perusahaan asuransi jiwa harus memenuhi kesehatan keuangan sesuai dengan ketentuan peraturan perundangundangan di bidang asuransi, seperti batas level solvabilitas (solvency margin.

\section{E. Risk Based Capital (RBC) / $\mathrm{X}_{1}$}

Nurfadila, Hidayat dan Sulasmiyati (2015) menjelaskan Pengertian Risk Based Capital berdasarkan peraturan pengerusi Badan Pengawas Pasar Modal (BAPEPAM) dan Lembaga Keuangan Nomor: PER-02 / BL / 2008 adalah "jumlah minimum tingkat solvabilitas yang ditetapkan, jumlah dana yang diperlukan untuk menutup risiko kerugian yang mungkin timbul akibat penyimpangan manajemen kekayaan dan kewajipan".

Semua perusahaan asuransi dan perusahaan reasuransi wajib memiliki 
Jurnal Semarak,Vol. 1,No.3,Oktober 2018 , Hal (88-106)

@ Prodi Manajemen Fakultas Ekonomi Universitas Pamulang

tingkat solvabilitas (Risk Based Capital) sekurang-kurangnya $120 \%$ daripada risiko yang mungkin timbul akibat penyimpangan dalam pengurusan kekayaan dan liabiliti atau serendah mungkin untuk mencapai 100\% sehingga dapat diberi kesempatan untuk melakukan penyesuaian dan meningkatkan batas solvensi dalam jangka waktu tertentu. Peraturan ini telah ditentukan oleh pemerintah dalam Keputusan Menteri Keuangan Nomor 424 / KMK.06 / 2003 tentang Kesehatan Keuangan Perusahaan Asuransi dan Perusahaan Reasuransi pada Pasal 2.

Risk Based Capital boleh menunjukkan kriteria yang syarikat itu sihat dan terjamin atau tidak. Kadangkala langkah Modal Berasaskan Risiko yang memenuhi standardnya sering digunakan sebagai alat promosi untuk menarik orang ramai untuk membeli polisi mereka.

\section{F. Beban Klaim / $\mathrm{X}_{2}$}

Beban klaim yang terdapat pada perusahaan asuransi umumnya merupakan beban yang berhubungan dengan pencairan yang dilakukan oleh nasabah termasuk tuntutan yang dipersetujui, tuntutan dalam proses penyelesaian, dan tuntutan yang telah berlaku tetapi belum dilaporkan. Beban tuntutan terjadi apabila terjadi kecelakaan, sakit yang harus dirawat di rumah sakit dan kematian atas tertanggung serta pemutusan kontrak dalam masa periode kontrak, atau dikenal dengan penebusan. Dalam hal ini perusahaan mengakui klaim sebagai pengurangan pendapatan premi, pada saat bukti- bukti yang sah telah diperoleh atasan tuntutan klaim yang terjadi. Pengakuan beban klaim dapat mempengaruhi besarnya laba perusahaan.

Karena klaim tidak dapat ditentukan kapasitasnya, maka klaim dicatat sebagai beban dalam tahun buku di mana klaim tersebut dibayar atau terjadi tanpa memperhatikan waktu pecatatan premi yang bersangkutan

"Tuntutan (klaim) adalah tuntutan yang dikemukakan oleh pihak yang diinsuranskan kepada syarikat insurans untuk kerugian yang dialami akibat kehilangan atau kerosakan terhadap sesuatu yang diinsuranskan”. Definisi beban tuntutan menurut Prihantoro (2009) merupakan sebagai berikut:

"Beban klaim adalah ganti rugi yang dibayarkan atau yang menjadi kewajiban kepada tertanggung dari pihak penanggung atau perusahaan asuransi (ceding company) sehubungan dengan telah terjadinya kerugian."

Dari pemahaman di atas dapat disimpulkan bahawa perbelanjaan tuntutan adalah pampasan yang dibayar oleh syarikat insurans kepada yang 
diasuransikan untuk terjadinya kerugian dari kejadian yang telah terjadi.

\section{G. Laba / Y}

Fokus utama penyata kewangan adalah keuntungan. Keuntungan adalah hasil daripada operasi sebuah syarikat dalam tempoh perakaunan. Suwardjono (2005) mentakrifkan keuntungan sebagai pendapatan tolak kos sebagai definisi struktur atau sintaksis kerana keuntungan tidak ditakrifkan secara berasingan daripada definisi pendapatan dan kos. Dalam konsep asas penyediaan dan penyampaian penyata kewangan, pendapatan (pendapatan) adalah peningkatan dalam keuntungan ekonomi dalam tempoh perakaunan dalam bentuk kemasukan atau penambahan aset atau pengurangan liabiliti yang mengakibatkan peningkatan ekuiti tidak diperolehi daripada sumbangan pelaburan (Zanora, 2013: 5).

Keuntungan adalah perbezaan di antara hasil yang direalisasikan yang timbul daripada transaksi dalam tempoh tertentu dengan kos yang ditanggung dalam tempoh tersebut. Keuntungan adalah jumlah sisa yang ditinggalkan selepas semua perbelanjaan (termasuk pelarasan penyelenggaraan modal jika ada) ditolak dari pendapatan. Jika beban melebihi pendapatan, maka jumlah sisa adalah kerugian bersih supaya keuntungan adalah perbezaan antara pendapatan dalam tempoh dan kos yang ditanggung untuk membawa keuntungan. Pertumbuhan keuntungan boleh dikira dari perbezaan dalam jumlah keuntungan dalam tahun berkenaan dengan jumlah keuntungan pada tahun sebelumnya dibahagikan dengan jumlah keuntungan pada tahun sebelumnya (Hamidu, 2013:3). Pengiraan pertumbuhan selaras dengan ungkapan yang dibuat oleh Ardiyasari (2012:6) yang menyatakan bahawa pertumbuhan keuntungan adalah peningkatan keuntungan yang diperoleh oleh syarikat berbanding dengan keuntungan tahun sebelumnya.

\section{H. Hipotesis}

Hipotesis adalah dugaan dalam suatu penelitian. Hipotesis bermanfaat untuk menduga suatu penelitian yang berdasarkan teori - teori yang ada. Hipotesis diuji sebagai berikut:

1. $\mathrm{H}_{\mathrm{o}}$ : risk based capital tidak berpengaruh satu - persatu terhadap laba pada perusahaan asuransi jiwa periode 2014 2016.

$\mathrm{H}_{\mathrm{a}}$ : risk based capital berpengaruh secara satu persatu terhadap laba pada perusahaan asuransi jiwa periode 2014 - 2016.

2. $\mathrm{H}_{\mathrm{o}}$ : beban klaim tidak berpengaruh secara satu persatu terhadap laba pada perusahaan asuransi jiwa periode 2014 - 2016.

$\mathrm{H}_{\mathrm{a}}$ : beban klaim berpengaruh secara satu persatu terhadap laba pada perusahaan asuransi jiwa periode 2014 - 2016. 
Jurnal Semarak,Vol. 1,No.3,Oktober 2018 , Hal (88-106)

@ Prodi Manajemen Fakultas Ekonomi Universitas Pamulang

3. $\mathrm{H}_{\mathrm{o}}$ : risk based capital dan beban klaim tidak berpengaruh secara bersama - sama terhadap laba pada perusahaan asuransi jiwa periode 2014 - 2016.

$\mathrm{H}_{\mathrm{a}}$ : variabel risk based capital dan beban klaim memiliki pengaruh secara simultan terhadap laba pada perusahaan asuransi jiwa periode 2014 - 2016.

\section{Kerangka Berpikir}

Berdasarkan tinjauan literatur yang telah dijelaskan sebelum ini, ia akan diuji sama ada pemboleh ubah modal berasaskan risiko dan perbelanjaan tuntutan menjejaskan pendapatan dapat digambarkan model sebagai berikut:
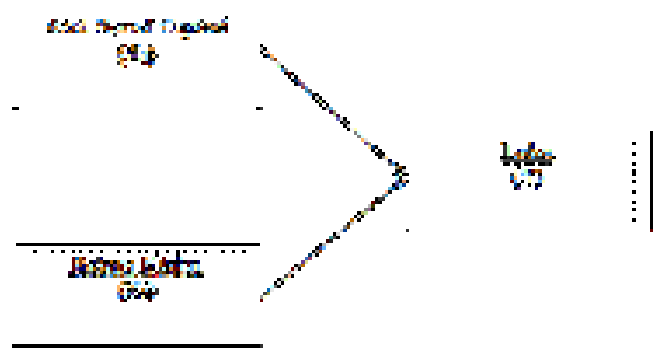

\section{Gammbar 1 Keranggka Berpiikir}

\section{METODA PENELITIIAN}

Objek dalam kajian ini adalah syarikat insurans hayat yang berdaftar di AAJI. Kaedah yang digunakan dalam kajian ini adalah kaedah kajian kes yang merupakan salah satu kajian deskriptif, dengan kajian ini dijangka akan mendedahkan secara mendalam pembolehubah yang akan dapat menggambarkan analisis modal berasaskan risiko dan beban tuntutan keuntungan.

Data yang digunakan dalam kajian ini, kedua-duanya bertujuan untuk menggambarkan dan menganalisis, diperoleh daripada data sekunder yang bersifat kuantitatif. Data sekunder adalah data yang maklumatnya diperoleh secara tidak langsung dari syarikat. Sedangkan menurut Kuncoro (2011:31), data sekunder merupakan "sumber data penyelidikan yang diperoleh oleh penyelidik secara tidak langsung melalui perantara (diperoleh dan direkam oleh pihak lain)". Data sekunder adalah "dalam bentuk data laporan kewangan dari penyata kewangan syarikat yang telah diaudit bagi syarikat insurans pada 31 Disember 2014 - 2016".

Sampel yang digunakan oleh kaedah pensampelan purposive. Kaedah persampelan purposive adalah "sampel diambil berdasarkan kriteria tertentu untuk mendapatkan sampel yang sesuai dengan tujuan penyelidikan" (Yama dan Adityawati, 2009:287). Sampel dalam kajian ini ditentukan berdasarkan beberapa kriteria atau pertimbangan seperti berikut: 1) Syarikat insurans jiwa yang berdaftar di Persatuan Insurans 
Jurnal Semarak,Vol. 1,No.3,Oktober 2018 , Hal (88-106)

@ Prodi Manajemen Fakultas Ekonomi Universitas Pamulang

Hayat Indonesia (AAJI) dari 2014-2016,

2) Syarikat yang menerbitkan laporan kewangan tahunan untuk tempoh 31 Disember 2014-31 desember 2016, dan telah diaudit oleh audior eksternal. 3) Perusahaan yang memiliki laporan keuangan mengenai risk based capital dan beban klaim.

Pengumpulan data dalam penelitian ini yaitu dengan menggunakan analisis laporan keuangan. Sampel dalam penelitiann ini yang akan dijadikan objek penelitian sebanyak 44 perusahaan Asuransi jiwa periode 2014 - 2016.

\section{ANALISIS DAN PEMBAHASAN}

\section{A. Sekilas Mengenai Objek Penelitian}

Perkembangan insurans pada Negara Indonesia mempunyai proses yang sangat panjang sehingga akhirnya kita dapat merasakan manfaatnya dengan mudah saat ini. Mengetahui sejarah insurans sangat diperlukan supaya kita tahu dengan sangat baik ins dan insuran insurans yang ramai di antara kita sekarang bertemu. Mempelajari sejarah insurans kemungkinan besar akan mudah memilih insurans terbaik sesuai dengan keperluan kita. Kerana tidak mungkin peristiwa tidak mempunyai hubungan dengan peristiwa sebelumnya, maka kredibiliti atau kualiti sebuah syarikat insurans sebenarnya dapat dikenal pasti melalui penataan sejarahnya.

Mengetahui sejarah insurans akan membuat anda ketat jika kebelakangan ini terdapat pelbagai jenis produk insurans yang ditawarkan supaya anda boleh memilih produk yang sesuai dengan keperluan anda. Phenonema boleh mengelirukan bagi mereka yang masih meletakkan produk insurans supaya mereka terdedah untuk membuat peruntukan dana untuk perlindungan, pelaburan atau penjimatan biasa.

Berikut adalah sejarah insurans di Indonesia, yang bermula dari zaman kolonial Belanda hingga era kemerdekaan sehingga kini anda dapat mempelajari latar belakang sehingga anda dapat menemukan produk asuransi yang tepat.

Nampaknya, sejarah insurans telah wujud sejak zaman purba SM. Sejak dahulu, orang telah memahami risiko dan cuba meminimumkan risiko yang berlaku dengan membuat perlindungan bersama.

Dalam artikel ini Cermati.com akan mengkaji semula sejarah insurans bermula dari idea pertama apabila insurans itu muncul sehingga perkembangannya begitu pesat di Eropah dan tentu saja bagaimana perkembangan asuransi di Indonesia.

Insurans global mempunyai beriburibu tahun sejak ia diwujudkan. Ada 
Jurnal Semarak,Vol. 1,No.3,Oktober 2018 , Hal (88-106)

@ Prodi Manajemen Fakultas Ekonomi Universitas Pamulang

perkara-perkara unik yang perlu anda ketahui tentang selok-belok peristiwaperistiwa di sebalik sistem ini yang telah digunakan dari zaman purba hingga ke zaman sekarang. Untuk memudahkan pembaca memahami sejarah dan kerumitan insuran, kajian semula kami terhadap sejarah insurans dibahagikan kepada bab dalam beberapa bab.

\section{B. Penemuan dan Pembahasan}

\section{Hasil Dari Pengujian Asumsi Klasik}

a. Hasil dari Pengujian Normalitas Data

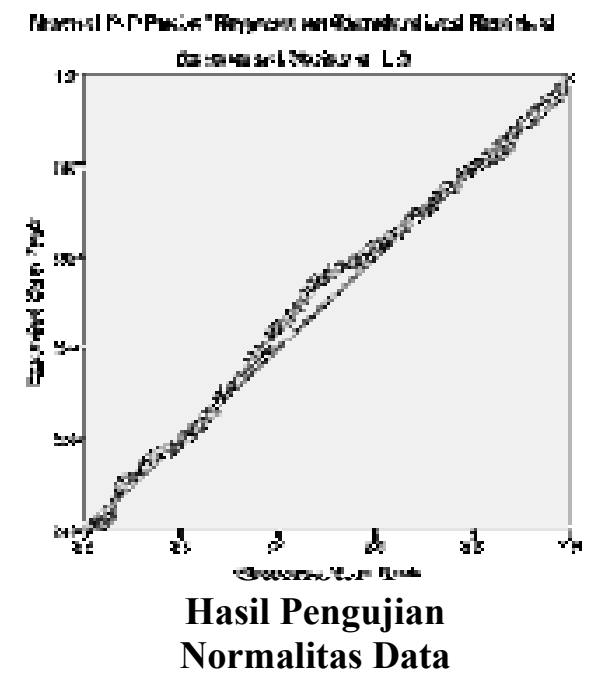

Dari grafik di atas dapat dilihat bahwa data penelitian memiliki penyebaran dan distribusi yang normal karena data memusat pada nilai purata dan median atau nilai plot PP terletak pada garis pepenjuru, boleh dikatakan bahawa data diedarkan secara normal. b. Hasil dari Pengujiian data Multikolinearitas

Tabel 1

Hasil Uji Multikolinearitas

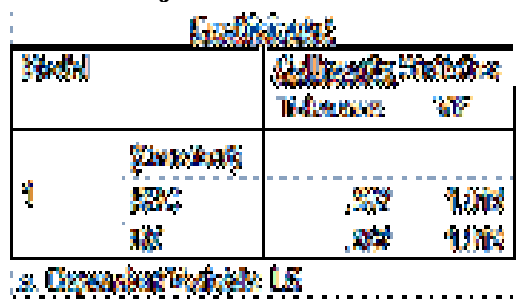

Nilai VIF yang diperbolehkan hanya mencapai 10 dan mempunyai angka tolerance lebih dari 0,10. Maka data di atas dapat dipastikan tidak terjadi gejala multikolinearitas. Karena data di atas menunjukan bahwa angka VIF lebih kecil dari angka 10 .

\section{c. Hasil dari Pengujian Autokorelasi}

\section{Tabel 2}

Hasil Pengujian Autokorelasi

\begin{tabular}{|c|c|c|c|c|c|}
\hline \multicolumn{6}{|c|}{ 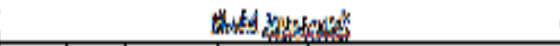 } \\
\hline Ph: & ह & k\% & 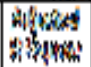 & 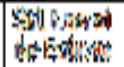 & 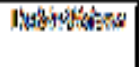 \\
\hline r & 840. & 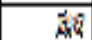 & 级 & 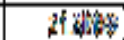 & Si隹 \\
\hline
\end{tabular}

Pada tabel di atas dilihat angka Durbin Watson (d) memilki angka 1,536, dilhat dari nilai durbin watson memiliki angka sebesar 1,272 maka hasil membuktikan tidak terjadi autokolerasi, karena nilai DW berada pada angka -2 sampai dengan +2 , maka dapat disimpulkan tidak ada autokorelasi baik positif maupun negatif. 
Jurnal Semarak,Vol. 1,No.3,Oktober 2018 , Hal (88-106)

@Prodi Manajemen Fakultas Ekonomi Universitas Pamulang

d. Pengujian data dengan Uji Heteroskedastisitas

Gambar 2

Hasil Pengujian Data Dengan

Heteroskedastisitas

Dotasen.

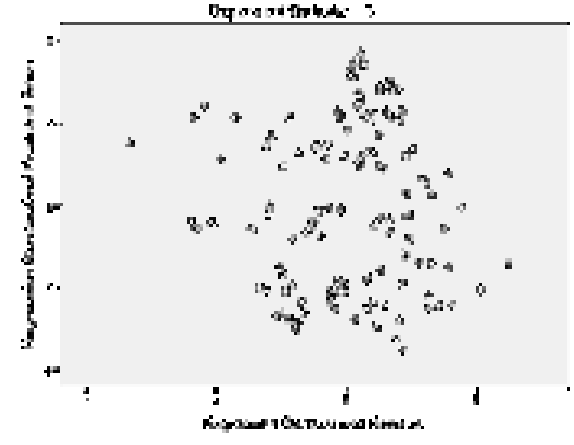

Pada gambar di atas terlihat pada gambar bahwa bulat-bulat menyebar di atas dan di bawah angka 0 pada sumbu $\mathrm{Y}$ dan tanpa terlihat pola tertentu. Dengan maka persamaan regresi linier berganda pada model ini tidak ada gejala atau tidak ada heteroskedastisitas.

\section{Hasil Analisis Regression Liniar} Berganda

a. Hasil Adjusted $\boldsymbol{R}^{2}$

Tabel 3

Hasil Adjusted $\mathbf{R}^{2}$

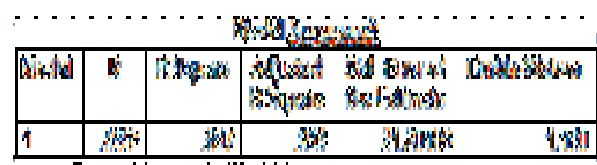

4 instis

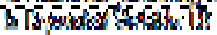

Berdasarkan dari tabel di atas nilai diketahui Adjusted $R$ square sebesar $\quad 0,693 \quad(69,3 \%), \quad$ ni menunjukkan bahawa dengan menggunakan model regresi yang diperoleh di mana pembolehubah bebas itu yaitu risk based capital dan beban klaim terdapat pengaruh terhadap laba dengan angka 69,3\%. Sedangkan memilki sisanya $30,7 \%$ yang dapat dijelaskan dengan faktor atau variabel lain yang tidak dapat diketahui dan tidak masuk pada / dalam analisis regresi ini, seperti aset manajemen, efisiensi profit dan lain-lain.

\section{b. Hasil Koefisien Persamaan}

\section{Regresi Linier Berganda}

Analisis regresi linier berganda adalah ujian yang digunakan untuk menentukan sejauh mana tahap pengaruh antara pembolehubah bebas (risk based capital dan beban klaim) terhadap variabel dependen (laba). Hasil pengaruh regresi linier berganda risk based capial dan beban klaim terhadap keuntungan adalah seperti berikut:

Tabel 4

Hasil Persamaan Regression Liniar Berganda

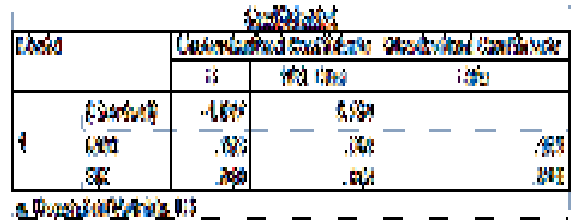

Tabel di atas dapat digunakan untuk menganalisa pengaruh risk based capital terhadap laba seperti berikut: 
Jurnal Semarak,Vol. 1,No.3,Oktober 2018 , Hal (88-106)

@ Prodi Manajemen Fakultas Ekonomi Universitas Pamulang

$\mathrm{Y}=\mathrm{a}+\mathrm{bx}_{1}+\mathrm{bx}_{2}+\mathrm{bx}$

$Y=-1,557+0,183 X_{1}+0,840 X_{2}$

Keterangan:

Y : Laba

$\mathrm{X}_{1}$ : Risk Based Capital

$\mathrm{X}_{2}$ : Beban Klaim

Koefisien persamaan regresi linear berganda di atas boleh ditafsirkan sebagai pekali regresi yang sama dengan -1,557 tunjukkan bahawa jika berubah risk based capital dan beban klaim bernilai 0 (nol) maka nilai laba akan terjadi penurunan sebesar 1,557 satuan. Variabel risk based capital 0,183 menunjukkan bahwa variabel risk based capital terjadi peningkatan 1 satuan maka akan meningkatkan laba akan terjadi peningkatan sebesar 0,183 satuan, dengan catatan variabel lain dianggap konstan. Variabel beban klaim 0,840 menunjukkan bahwa jika variabel beban klaim mengalami peningkatan 1 satuan maka akan terjadi peningkatan laba sebesar 0,840 satuan, dengan catatan variabel lain dianggap konstan.

\section{Hasil Pengujian Data Hipotesis}

\section{a. Hasil Pengujian Data Statistik Secara Simultan}

Uji simultan dapat dilakukan dengan tujuan untuk menganlisa pengaruh variabel risk based capital dan beban klaim secara simultan terhadap variabel laba. Berikut ini merupakan hasil dari pengujian secara simultan, diperoleh hasil uji Anova seperti berikut:

Tabel 5

Hasil Pengujian Statistik Secara Simultan

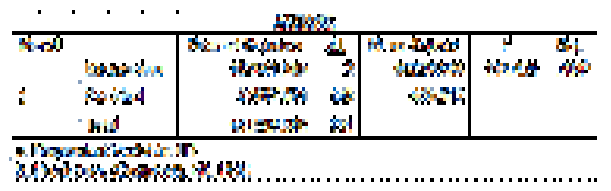

Berdasarkan data (tabel) di atas diperoleh hasil nilai signifikan sebesar 0,000 ini membuktikan bahwa ketentuan nomor tiga (3) berlaku dalam penelitian ini bahwa $\mathrm{H}_{\mathrm{o}}$ ditolak dan $\mathrm{H}_{\mathrm{a}}$ diterima. Hasil pengujian secara simultan ini menyatakan bahwa hasil pengujian secara simultan di atas benar adanya.

Dalam penelitian ini juga diperoleh nilai $F_{\text {hitung }}$ sebesar $148,675>$ nilai $F_{\text {tabel }}$ sebesar 3,07. Dapat dibuat suatu kesimpulan, bahwa memiliki pengaruh yang signifikan antara variabel independen terhadap variabel dependen. 
Jurnal Semarak,Vol. 1,No.3,Oktober 2018 , Hal (88-106)

@ Prodi Manajemen Fakultas Ekonomi Universitas Pamulang

b. Hasil Pengujian Secara Parsial

Tabel 6

Hasil Pengujian Secara Parsial

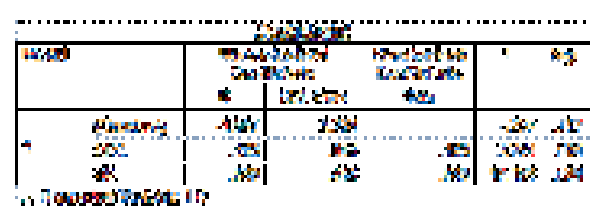

Hasil pengujian secara parsial bahwa terlihat variabel independen (risk based capital dan beban klaim) berpengaruh secara parsial terhadap laba.

\section{KESIMPULAN DAN SARAN}

\section{A. Kesimpulan}

Analisis dari kegiatan meneliti ini dilakukan bertujuan untuk mengetahui apakah terdapat pengaruh risk based capital dan beban klaim terhadap laba. Berdasarkan hasil yang dijabarkan dipenjelasan sebelumnya, maka kesimpulan dalam penelitian adalah sebagai berikut:

1. Penelitian ini menyatakan bahwa secara satu persatu atau berdasarkan hasil pengujian secara satu persatu menunjukkan bahwa variabel risk based capital berpengaruh terhadap laba.

2. Penelitian ini menyatakan bahwa secara satu persatu atau berdasarkan hasil pengujian secara parsial menunjukkan bahwa beban klaim berpengaruh terhadap laba.
3. Penelitian menyatakan bahwa secara bersama - sama atau berdasarkan hasil pengujian secara simultan menunjukkan bahwa memiliki pengaruh signifikan antara risk based capital dan beban klaim terhadap laba.

\section{B. Saran}

Hasil kajian untuk memberikan beberapa saran yang dapat disampaikan, yaitu:

1. Diharapkan lebih memahami risk based capital dan beban klaim perusahaan asuransi jiwa di indonesia. Dengan cara membaca banyak referensi hal ini dikarenakan perusahaan asuransi jiwa di indonesia sedang banyak peminat untuk menginvestasikan uang atau membeli produk asuransi kesehatan.

2. Seharusnya pihak manajemen lebih memperhatikan faktor apa saja yang dapat meningkatnya keuntungan suatu usaha insurance jiwa pada negara indonesia, hal ini guna meningkatkan persaingan asuransi jiwa di indonesia.

3. Bagi investor, untuk meningkatkan persaingan di dunia asuransi, diharapkan investor memperhatikan faktor - faktor lainnya yang dapat menguntungkan perusahaan maupun investor itu sendiri sebelum melakukan investasi diperusahaan asuransi tersebut.

4. Bagi peneliti selanjutnya 


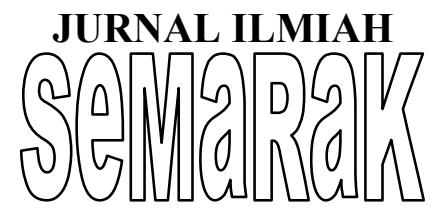

P-ISSN 2615-6849, E-ISSN 2622-3686

Jurnal Semarak,Vol. 1,No.3,Oktober 2018, Hal (88-106)

(a)Prodi Manajemen Fakultas Ekonomi Universitas Pamulang

a.Berdasarkan hasil penelitian variabel

risk based capital dan Beban Klaim

secara simultan berpengaruh $69,3 \%$

terhadap Laba berarti terdapat

$30,7 \%$ faktor lainnya yang

berpengaruh terhadap Laba

Asuransi. Penelitian selanjutnya

diharapkan menggunakan lebih

banyak variabel.

b. Objek dalam penelitian

menggunakan asuransi jiwa yang

terdaftar di AAJI, untuk penelitian

selanjutnya diharapkan untuk

menambah sektor perusahaan

asuransi kerugian sebagai sampel

penelitian.

c.Penelitian ini menguji data menggunakan aplikasi SPSS 23, untuk penelitian selanjutnya dapat menggunakan E-views.

d. Penelitian ini mengambil sampel 3 tahun periode laporan keuangan, diharapkan penelitian selanjutnya dapat meenambahkan periode tahun laporan keuangan.

\section{DAFTAR PUSTAKA}

Ardiansyah, M. (2010). Analisis Kesehatan Keuangan Perusahaan Asuransi Jiwa Dengan Metode RBC Pada PT. asuransi Jiwa Mega Life.

Agustin, E. N. (2016). Analisis Faktor Faktor Yang Mempengaruhi Profitabilitas, 1.

Fahmi, I. (2014) Analisis Laporan Keuangan. Bandung: Alfabeta.
Hemut,G , Dong, M, Gal, J (2016). The evolution of insurer portfolio investment strategies for long-term investing. OECD Journal: Financial Market Trends Volume 2016 Issue 1, 48.

Inderakasih, A. (2014). Pengaruh Pendapatan Premi, Klaim dan Hasil Investasi Terhadap Laba.

Khotimah, H. (2014). Pengaruh premi, klaim, hasil investasi dan underwriting terhadap laba perusahaan asuransi syariah periode 2008-2012 (PT. Asuransi Kerugian Sinarmas syariah). Jurnal Universitas Islam Negeri Jakarta, 90.

Latifah, (2014), pengaruh pendapatan premi, hasil investasi dan bebean klaim terhadap profitabilitasPerusahaan asuransi yang terdafar di bursa efek indonesia. Jurnal Universitas Mercu Buana, 100.

Nugraha, W. A. (2014). Pengaruh Underwriting, Beban Klaim dan Hasil investasi Terhadap Laba Bersih Pada Perusahaan Asuransi Kerugian yang terdaftardi BEI periode 2008-2012. Jurnal Universitas Mercu Buana, 30.

Stern, D, S. (2000). An Economic Analysis of Life Insurance Company Expenses. North American Actuarial Journal, 23.

Jr, H. R., \& Schellhorn, C. (2000). Life Insurer Cost Efficiency Before and After Implementation of the NAIC Risk Based Capital Standars. Life Insurer Cost Efficiency Before and After Implementation of the NAIC Risk Based Capital Standars, 1.

Marwansyah, S, (2017). Analisis Hasil Investasi, Pendapatan Premi dan Beban Klaim Terhadap Laba Perusahaan Perasuransian Inonesia. Jurnal Ekonomi, Akutansi dan Bisnis, Vol 5, No. 2, 08.

Supriyono, A. E. (2013). Pengaruh Risk Based Capital terhadap Tingkat Profitabilitas pada Perusahaan Asuransi Syariah. 